\title{
CAREER CONSTRUCTION AS A WAY OF RESOLVING CAREER INDECISION
}

\section{J. G. Maree}

Department of Educational Psychology

University of Pretoria

Pretoria, South Africa

e-mail: kobus.maree@up.ac.za

\section{ABSTRACT}

This article reports on the value of career construction counselling for a woman who was undecided about the career she should follow. The participant was purposefully selected from a number of people taking part in a career construction counselling course. An intrinsic, single case study design was adopted on the basis of a qualitative, interpretive paradigm. The Career Construction Interview ( $\mathrm{CCl}$ ) was used to collect qualitative data, and Savickas's eight-step strategy was followed to complete the participant's life portrait. The results suggest that the intervention helped the participant clarify and resolve her career indecision. Future research should focus on the use of this intervention in different contexts and on its longer term impact.

Keywords: career indecision, construction counselling, life portrait, career construction interview, case study

\section{INTRODUCTION}

Many people, at various stages of their career-lives, find it difficult to understand their previous career-related decisions (Lease 2004). They then often turn to career counsellors for advice. Savickas (2005; 2010) maintains clients who show career indecision (which is, in essence, an indication of pending transformation and change in outlook) demonstrate a lack of the career control needed to make sound career-life decisions. Stringer, Kerpelman and Skorikov (2011), too, highlight the need to help clients plan their career journeys, reduce their career indecision, and enhance their decision-making capacity by equipping them with the skills required to manage career-related transitions.

Maree (2013, 2015) distinguishes between two broad groups of people facing points of transition that may result in career indecision, which can be defined as 'an inability to make a decision about the vocation one wishes to pursue' (Guay, Sene'cal, Gauthier and Fernet 2003, 165). The first group of people may experience career indecision when they are expected to make a 'natural' transition or face a 'natural' crossroads requiring career-related decisions. These decisions include having to choose particular subjects, a type of school, a field of study, 
a tertiary training institution, or a specific employment opportunity. The second group of people begins to question as to whether the choices they made in terms of, for instance, a school, a subject set, a field of study, a career, or an employer is the 'right' (appropriate) choice. Various techniques, strategies, and interventions are at the disposal of career counsellors to help both groups of clients resolve their career indecision. Career counsellors can implement a predominantly 'positivist' (quantitative), a predominantly narrative or storied approach, or an integrated approach (i.e. the combination and integration of quantitative and qualitative approaches) to help their clients transition the impasse brought on by their career indecision.

Different conceptual frameworks have been used in the past to investigate and interpret the phenomenon of career indecision, which will now be discussed briefly.

\section{RATIONALE FOR THE STUDY}

Much has been written about the manifestation of career indecision at undergraduate level at university (demonstrated by, for instance, student dropout and student migration from one field of study to another), yet very little has been reported on career indecision at postgraduate level. However, I have personally encountered a substantial number of postgraduate students with career indecision in my capacity as a university lecturer, as a psychologist in private practice, and as the presenter of workshops on career construction. Over time, I have moved from using a positivist approach to resolving postgraduate students' indecision to adopting an integrated, qualitative-quantitative approach to the problem. The turning point for me came in 1993 when (after attending a course on the administration of the Myers-Briggs Type Inventory) I realised that the answer sheet of the Jung Personality Questionnaire (which had been in use in South Africa for more than 40 years) contained a serious error. Testees' preferences are indicated on four dichotomous scales (extraversion versus introversion, sensing versus intuition, thinking versus feeling, and judging versus perceiving. The fourth basic preference pair of type theory (Martin 1995) recorded on the answer sheet should have been anchored by the J (judging) on the left and P (perceiving) on the right. Instead, it read: P (left) and J (right). Clearly, an inattentive typist had made a typing mistake many years previously. I brought the error to the attention of the distributors of the test, and the correction was duly made.

Misleading information was thus given to clients for more than 40 years, and there is every likelihood that many colleagues are still using the incorrect version of the answer sheet. The seriousness of the oversight is that this questionnaire was used to select students at tertiary institutions in South Africa.

Numerous publications over the past two or three decades have pointed to the value of a 
narrative approach to career counselling. Clients consistently report having experienced the strategy as respectful and useful, hence my decision to report on the implementation of a qualitative (storied) approach to this kind of counselling. (This is the real reason for changing my approach.)

\section{Brief overview of research on career indecision}

Guay, Sene'cal, Gauthier and Fernet (2003) designed and tested a model of career indecision grounded in self-determination theory (SDT), which holds that healthy relationships between college students and their parents and peers impact positively on career indecision and vice versa. More particularly, the model holds that more controlling behaviour on the part of parents and peers correlates strongly positively with lower self-efficacy and less independence in decision-making capacity. The researchers found in their study that the support of peers and parents in students' autonomy acquisition promoted the students' self-confidence with regard to their career decision making and enhanced their observed self-sufficiency. These findings correlate positively with those of Creed, Buys, Tilbury and Crawford (2013) and Garcia, Restubog, Toledano, Tolentino and Rafferty (2012) whose research showed that people who display a strong desire to become exceptionally skilful at tasks are more positive, give evidence of enhanced career-related ambitions, demonstrate enhanced self-efficacy levels and, consequently, exhibit diminished levels of career indecision. Gianakos’ (2001) research reveals that career decision self-efficacy (Taylor and Betz 1983) mediates students' decision-making capacity and decreases career indecision.

This all shows that enhanced self-efficacy levels, independence, a positive attitude, and autonomy contribute to a decrease in career indecision and counsellors should therefore do all they can to promote these aspects.

\section{Overview of different approaches to dealing with career indecision}

As stated previously, career counsellors have drawn on different epistemological approaches to inform their interventions aimed at dealing with career indecision.

Savickas (1995) explains that career indecision was initially considered an objective phenomenon. Early 20th century career counsellors, influenced by the work of Parsons (2005), consequently based their efforts to help clients deal with career indecision on a 'positivist' paradigm involving the theory and principles of logical positivism (also see Richardson 1993), which stipulated the need for 'reliable' and 'valid' measuring instruments and techniques to assess career indecision. Career indecision was initially also considered a dichotomy (i.e. clients 
were categorised as either equipped to make viable career decisions or not equipped to do so). Over time, the belief grew that clients could be plotted on a one-dimensional continuum anchored by 'undecided' and 'decided'. This view was in turn replaced by the belief that career indecision should be seen as a multidimensional phenomenon (i.e. clients with career indecision should be categorised into different subcategories of indecision). Scholars such as Blustein, Ellis and Devenis (1989), Gati, Osipow, Krausz and Saka (2000), Gati, Krausz and Osipow (1996), and Savickas and Jarjoura (1991) devised assessment instruments to determine the nature of clients' indecision and began to design different interventions for different subcategories of indecision.

I agree that the 'positivist' approach is not sufficient for designing a satisfactory intervention for career indecision. Such indecision should be regarded as a subjective experience, as an indirect manifestation of change taking place, and as a new identity being shaped (Savickas 1995). Cochran (1991) speaks of 'wavering' to explain what happens during indecision: the undecided person moves back and forth (and side to side), trying to 'construct the whole that will clarify the parts' (Savickas 1995, 3). Wavering thus constitutes the pivotal search for fundamental life themes.

\section{A constructivist perspective on how to deal with career indecision}

Arguing from a constructivist perspective, Savickas $(1995,365)$ states that ' $[\mathrm{t}] \mathrm{he}$ career indecision experienced by adolescents and young adults may occur, in part, because they have not recognized their life themes'. Savickas (2005) adds that career indecision frequently signifies hesitation before transformation occurs and presents oscillatory movement in search of meaning. When career indecision is at issue, career counsellors working from a career construction perspective help their clients identify major life themes, choose careers, construct themselves, and, in the process, make meaning of their lives.

In the following section, I elaborate on key aspects of career construction that enable career counsellors to help clients deal with career indecision.

\section{CONSTRUCTION OF THE SELF AS STORY}

To establish a clear sense of self and a stable self-concept, one first needs the ability to narrate one's career-life story (Di Fabio and Maree 2013). Self-construction entails construction of the self as story and enhancement of the self as an inner compass to deal with transitions. Savickas (2013) blended the psychodynamic approach with differential and developmental approaches to create a meta-theoretical framework known as career construction counselling. This meta- 
theory explains the interpersonal processes people use to construct themselves; processes that direct their vocational behaviour. It emphasises the importance of meaning-making in and through their careers.

\section{FACILITATING NARRATABILITY}

Helping clients to say who they really are by getting them to enunciate and hear their careerlife stories (autobiographical reasoning, Savickas (2009a) lies at the heart of career construction counselling. Being able to narrate one’s career-life story (narratability; Savickas 2005; Savickas et al. 2009) facilitates the moderation and eventually the resolution of indecision because it helps clients locate career choice issues in the bigger pattern of lived meaning. Narratability involves the use of narratives to reduce confusion, end doubt, shed light on career-related choices, and, ultimately, promote clients’ capacity to make decisions.

\section{(AUTO-)BIOGRAPHICITY: RECONSTRUING PAST STORIES}

\section{Encouraging (auto-)biographicity}

Career-life stories, often characterised by numerous twists and turns in the storyline and substorylines, are elicited and used to deal with repeated transitions. These stories help to resolve indecision by shedding light on the digressions in people's career-lives and by inspiring action and forward movement. In narrating the stories, clients are enabled to listen to themselves and helped to reconstruct their past. Biographicity (Alheit and Daussien 1999) occurs when clients identify their central life themes (as revealed in their career-life stories) and become able to use work to heal themselves. Clients reinterpret and adapt their former stories so that they can draw on advice from within to help terminate career indecision and pave the way for forward movement (Savickas 2011). Otherwise stated, clients are inspired and energised by their biographical agency to transition from hesitation to transformation.

\section{Creating a holding environment}

When clients are helped by career counsellors to make use of their elicited career-life stories (autobiographies) to negotiate repeated transitions (Savickas 2009b), they often discover an existing but dormant ability to exploit their career-stories. This enables them to take care of or 'hold' (Winnicott 1969) themselves if and when change happens and impacts on their careerlife story - often resulting in the career indecision arising. 


\section{Constructing a biographical bridge}

When biographicity occurs, clients are enabled to join micro-aspects of their lives into a 'grand' story thereby building a 'biographical bridge' across the divide between indecision and sound decision making. Retrospective reflection (facilitated during career counselling) is transformed into prospective reflexivity and, eventually, life designing (Savickas 2005, 2011, 2015a and b).

\section{Self-authoring of the career-life story}

Career construction counselling involves the search for a strategy to enable clients to author their career-life stories. Career construction counselling helps career counsellors achieve this outcome by first enabling clients to recount (narrate) their career-life stories and then to enact these stories purposefully and intentionally.

Career construction counselling is thus a means of enhancing self-efficacy levels and independence, instilling a positive attitude, and fostering autonomy in clients - the very factors that can contribute to a decrease in career indecision.

\section{Creating a 'sacred space'}

Clients need a safe or 'sacred' space where they can feel 'safe' (at home) in the company of the career counsellor - a place where he or she can ask them about their earliest recollections ('deepest secrets'). Asking the first four questions listed in Table 2 can help career counsellors create such a safe space.

\section{USING EARLIEST RECOLLECTIONS: THEORETICAL BACKGROUND}

According to Adler (1932), the concept 'chance' earliest memories does not make sense. Earliest memories, in fact, exemplify clients' career-life stories. He adds the following about the value of earliest memories in career counselling: 'If ever I am called on for vocational guidance, I always ask how the individual began and what he was interested in during his first years. His memories of this period show conclusively what he has trained himself for most continuously: they reveal his prototype and his underlying scheme of apperception' (Adler 1932, 144).

Earliest recollections are used to clarify clients' fundamental preoccupations and major life themes. Adler (1932) maintains that clients draw on implicit messages from their subconscious - conveyed through their earliest recollections - to soothe, reprimand, caution, comfort, motivate, or inspire themselves. These outcomes are achieved by revisiting strategies and plans of action that worked for them in the past and using them to face current and future 
challenges. Career counsellors refrain from 'advising' clients and interpreting these fundamentally important stories. Instead, they gently and respectfully help clients recount and then reflect on and interpret these recollections themselves. The individual stories are eventually connected into an articulate and interrelated story that helps clients deal with impasses and discontinuation and inspires forward movement (Hartung 2011). It enables clients to move from passive suffering to active mastery of pain/challenges.

\section{From theory to practice: Career counselling as a three-act 'drama'}

According to Savickas (2011, 42): 'Similar to a three-act drama, career counseling has three parts. The three parts may be portions of a single interview or three separate interviews' (see Table 1). In career construction counselling, clients are introduced to their career counsellors during the first act (comprising the administration of the Career Construction Interview (CCI) (see the Methodology section). In the second act, the client's life portrait is discussed and related to why he or she sought career counselling in the first place. In the third act, the career counsellor counsels the client on the reasons for seeking career counselling. Savickas (2011) states that 'during the first act clients construct their careers through short stories, during the second act practitioners re-construct the small stories into a large story, and during the third act client and practitioner co-construct a revised identity narrative, new intentions, and possible actions’ (43). This process is summarised in Table 1.

Table 1: The threefold organisation of career construction counselling (Compiled from Savickas 2011)

\begin{tabular}{|c|c|c|c|c|}
\hline $\begin{array}{l}\text { Elements of } \\
\text { three-act drama }\end{array}$ & $\begin{array}{l}\text { Three aims of } \\
\text { career } \\
\text { construction } \\
\text { counselling }\end{array}$ & $\begin{array}{l}\text { Actions taken to } \\
\text { realise the three aims }\end{array}$ & $\begin{array}{l}\text { Part of career } \\
\text { construction } \\
\text { realised }\end{array}$ & $\begin{array}{l}\text { Phases in crafting } \\
\text { of life portrait }\end{array}$ \\
\hline $\begin{array}{l}\text { Act 1: Character } \\
\text { is introduced }\end{array}$ & $\begin{array}{l}\text { Part 1: } \\
\text { Elicitation of } \\
\text { clients' career } \\
\text { stories }\end{array}$ & $\begin{array}{l}\mathrm{CCl} \text { and auxiliary } \\
\text { instruments/ strategies } \\
\text { are administered to } \\
\text { introduce clients to } \\
\text { counsellors and to } \\
\text { themselves }\end{array}$ & $\begin{array}{l}\text { Clients construct their } \\
\text { careers by narrating } \\
\text { several short stories }\end{array}$ & $\begin{array}{l}\text { Clients' small (micro-) } \\
\text { narratives are elicited }\end{array}$ \\
\hline $\begin{array}{l}\text { Act 2: Basic } \\
\text { conflict is } \\
\text { presented. Insight } \\
\text { is achieved and } \\
\text { defining moments } \\
\text { are uncovered }\end{array}$ & $\begin{array}{l}\text { Part 2: Clients } \\
\text { are asked to } \\
\text { authorise their } \\
\text { career }\end{array}$ & $\begin{array}{l}\text { Counsellor reads } \\
\text { clients' life portraits, } \\
\text { which are discussed } \\
\text { and related to the } \\
\text { reason for seeking } \\
\text { counselling. New } \\
\text { interpretation emerges }\end{array}$ & $\begin{array}{l}\text { Counsellor } \\
\text { deconstructs and } \\
\text { reconstructs (weaves) } \\
\text { these micro-stories } \\
\text { into a larger story }\end{array}$ & $\begin{array}{l}\text { These narratives are } \\
\text { deconstructed, } \\
\text { reconstructed, and } \\
\text { crafted into a } \\
\text { preliminary draft of a } \\
\text { larger narrative by } \\
\text { counsellor }\end{array}$ \\
\hline $\begin{array}{l}\text { Act 3: Change } \\
\text { and revitalisation } \\
\text { are inspired by } \\
\text { the new insights }\end{array}$ & $\begin{array}{l}\text { Part 3: } \\
\text { Counsellor } \\
\text { facilitates } \\
\text { 'movement' by } \\
\text { clients }\end{array}$ & $\begin{array}{l}\text { Actual counselling } \\
\text { takes place, aimed at } \\
\text { prompting clients to } \\
\text { 'move' }\end{array}$ & $\begin{array}{l}\text { Clients and counsellor } \\
\text { co-construct a revised } \\
\text { vision and mission } \\
\text { statement (VMS). } \\
\text { New aims and } \\
\text { achievable actions are } \\
\text { formulated. Intention } \\
\text { is operationalised }\end{array}$ & $\begin{array}{l}\text { 'Final' life portrait is } \\
\text { co-constructed with } \\
\text { counsellor and } \\
\text { authorised by clients }\end{array}$ \\
\hline
\end{tabular}


The table shows that allowing clients' larger or grand career-life stories to emerge guides the career counselling process (even though career counsellor and clients initially focus on the 'smaller' stories that constitute the clients' career-life stories).

A case study, based on a qualitative, interpretive paradigm can best shed light on the unique story of a postgraduate student struggling with career indecision.

\section{PURPOSE OF THE STUDY}

The study on which this article is based, sought answers to the following questions.

a. What were the career counselling needs of a particular postgraduate student in psychology struggling with career indecision?

b. How did this student experience career construction counselling?

c. How did the counsellor use the CCI to deal with the career indecision of the student?

\section{METHOD}

\section{Participant and context}

The participant was a purposefully selected 26-year-old English-speaking white woman (Sylvia - a pseudonym). The selection criteria called for someone who had indicated a need for career counselling. Sylvia and a number of other participants volunteered to act as the 'client' during a live demonstration that formed part of a course in career construction counselling in 2015. They wrote their names on small pieces of paper that were thrown into a hat. Sylvia's name was randomly drawn by a participant who had not volunteered her name. The sampling style can therefore be classified as 'convenience sampling' (with an element of randomness). At the end of this type of demonstration, I usually ask three attendees to thank the participant and tell her what her story meant to them individually. All attendees are routinely reminded of the ethical aspects of the demonstration (e.g. no one may abuse a client's privacy by discussing aspects of his or her case).

Sylvia's parents divorced when she was very young, a traumatic experience for her. At the time of the interview, she had an Honours degree in Psychology and was enrolled for a Master's degree, but she felt she had lost her passion for the subject. Superficially, Sylvia appeared undecided about what she should do after obtaining her Master's degree, but, at a deeper level, her uncertainty seemed to be based on her not really knowing which subfield of psychology she actually wanted to pursue. 


\section{Mode of inquiry}

The study was based on naturalistic inquiry as the research methodology in the form of a single, explorative, descriptive, instrumental case study.

\section{Data-gathering strategy}

\section{Career Construction Interview (CCI)}

The CCI comprises five questions in addition to the opening question, 'How can I be useful to you?' (see Table 2). Clients' responses to this question reveal what they hope to get out of the career counselling. The first four career-life story questions shed light on clients' career-life stories, after which their three earliest recollections are obtained.

Table 2: Career Construction Interview (Savickas 2011)

\begin{tabular}{|l|l|l|}
\hline & Question & Rationale \\
\hline & $\begin{array}{l}\text { How can I be useful to you as you } \\
\text { construct your career? }\end{array}$ & $\begin{array}{l}\text { Clients, who are regarded as the sole experts on their lives, } \\
\text { should communicate their goals and set the scene for } \\
\text { counselling. }\end{array}$ \\
\hline 1. & $\begin{array}{l}\text { Whom did you admire or who were } \\
\text { your three role models before you } \\
\text { were six years old? Why? }\end{array}$ & $\begin{array}{l}\text { Role models represent clients' self-concepts and central life } \\
\text { goals; they represent 'a blueprint for self-construction' } \\
\text { (Savickas 2015c). }\end{array}$ \\
\hline 2. & $\begin{array}{l}\text { What is your favourite a) magazine, b) } \\
\text { TV programme, and c) website? Why? }\end{array}$ & $\begin{array}{l}\text { Responses to these three sub-questions indicate environments } \\
\text { that fit clients' lifestyles and their preferred settings for enacting } \\
\text { the self. }\end{array}$ \\
\hline 3. & $\begin{array}{l}\text { What is your favourite story - book or } \\
\text { movie or book turned into movie? }\end{array}$ & $\begin{array}{l}\text { Reveals characters that faced the same problems as the } \\
\text { clients and shows how the characters solved these problems. }\end{array}$ \\
\hline 4. & $\begin{array}{l}\text { What are your three favourite mottoes } \\
\text { or quotations? }\end{array}$ & Reveals clients' advice to themselves at a given moment. \\
\hline 5. & $\begin{array}{l}\text { What is the first thing you remember } \\
\text { about your life? What are your earliest } \\
\text { recollections? }\end{array}$ & $\begin{array}{l}\text { Earliest memories reveal core problems clients face } \\
\text { (preoccupations) but also clients' advice to themselves. }\end{array}$ \\
\hline
\end{tabular}

The three acts of career construction counselling discussed earlier were carried out to elicit Sylvia's career-life story as part of the data-collecting process. Career construction (Savickas 2005) and self-construction (Guichard 2009) were facilitated. Sylvia's self-portrait was then completed by carrying out the eight steps recommended by Savickas (2011). Finally, Sylvia's vision and mission statement was drafted.

\section{Rigour of the study}

Various strategies were implemented to ensure trustworthiness at all stages of the data analysis, namely preparing, organising, and reporting on the data (Elo et al. 2014). Peer debriefing and participant review were carried out, and verbatim reporting of the data and low inference explanations were facilitated. Selective use of the data was avoided. I, as the career counsellor, gave feedback to Sylvia during all the phases of the research, and I also asked her to authorise 
every stage of the intervention.

\section{Career-life story assessment and intervention}

The rationale proposed by Savickas (2011) served as the guideline for analysing the client's responses to the questions in Table 2 .

\section{Steps followed in analysing the three earliest recollections (Maree 2013).}

The following five steps were followed.

1. I carefully noted and wrote down Sylvia’s own words.

2. I wrote down the first verb Sylvia used because it indicated how she connected with her career-life world.

3. I noted repeated words, phrases, and expressions (which cast light on her central life themes).

4. Once she had recounted her three earliest recollections, I asked her to imagine that they would 'appear in tomorrow's newspapers' and also requested her to 'to add a heading or a headline for each'. I said that each headline had to contain a verb. I explained that we would work together to finalise the title but that she had to make a first attempt at capturing the essence of the story in a heading. I added that, like a pendulum, the title would 'swing to and fro' until it finally came to rest when she and I were satisfied that the headings truly captured the essence of her recollections. Once all three headings had been finalised, I asked her to imagine that the three stories were due to appear in an omnibus edition and that she had to add an encompassing/inclusive heading for the omnibus.

5. I asked Sylvia which feelings or emotions she associated with the events contained in her three earliest recollections (Sweeney and Myers 1986).

\section{Noting repeated words or phrases.}

I carefully noted repeated words or expressions and made sure that Sylvia heard what she had told herself by repeating her own words and expressions to her. I authenticated her words by prompting her to say these words and expressions out loud (to make sure that she experienced them as real).

\section{Observing Sylvia}

I observed Sylvia closely and carefully noted her bodily movements, which were later integrated into the career counselling sessions (Savickas 2009a). 


\section{Commencing feedback}

I started the feedback with a discussion on the earliest recollections (Sylvia's 'secrets') and drew her attention to the fact that they were filled with meaning, despite seeming superficial. I said that they reflected Sylvia's central life themes and her advice to herself.

\section{Creating a life portrait}

Savickas' (2011) eight-step strategy was implemented in order to compose a life portrait or future scenario for Sylvia. I first considered her response to the first question in the CCI (which provided a strong indication of what she hoped to achieve during the career counselling sessions) when I crafted her life portrait.

\section{Procedure}

The intervention (individual narrative career counselling) comprised two sessions. The CCI was completed during the first session (which lasted 70 minutes). In Session 2 (which lasted 100 minutes), I read Sylvia's career-life story back to her so that she could authorise (corroborate) it. She and I then co-constructed her life portrait, and we agreed on a number of action steps (see the Results section). Sylvia and I later communicated by email on a number of occasions.

\section{Ethical issues}

Informed consent was obtained from Sylvia, and confidentiality was maintained. Written permission was also obtained for the anonymous publication of the case study.

\section{RESPONSES TO QUESTIONS IN THE CCI}

In response to the question, 'How can I be useful to you?', Sylvia responded: ${ }^{1}$

'I have lost some of my passion for my field of study.' (She looks up, frowns lightly, and then resumes): 'Moreover, I am no longer sure if (and when) I should pursue a $\mathrm{PhD}$ after my initial studies, go into private practice immediately or work with somebody else in his or her practice first'. She sighs and then continues: 'I want to learn more about myself that I did not know before'. (turns her head and smiles gracefully and gently)

\section{Role models}

'The Spice Girls. They were kind, friendly, arty, sporty and beautiful, inside and outside. One of them had a cross tattoo on her arm to express her religious feelings. They just were themselves. I loved their Spice Girls scrap book, which was a way of exercising their creativity.' 
'My mother': She was very independent, caring, compassionate' (smiles; moves her legs). 'The considerate way she interacts with others ... she takes time getting to know people' (opens her hands); 'always feels as if she is only speaking to you. She is kind and gracious.'

(Closes and swiftly opens her eyes) 'I admired a ballerina from the Bolshoi ballet group. She was disciplined, graceful, dedicated, passionate about dancing ... took time to sign my book (the personal touch impressed me immensely).'

'My Grade 2 teacher. She was a petite, small woman' (Sylvia, too, is a beautiful, petite young woman). 'I admired her because of her creative teaching methods. She turned learning into fun. Class became fun. She took a personal interest in each child; made that child feel special.'

\section{Favourite magazine, television show, and website}

(Smiles brightly) 'Elle. The exciting pictures, the sense of creativity, the artistic themes, the fashion aspects, the striking, different colours.' (Smiles) 'I, enjoy drawing, using creative fonts ... I started compiling a quote book from an early age on. I love cooking for other people; exercising; reading; singing.'

'The fixer. It is about a woman who engages in problem-solving; works with people and their dilemmas. But also The good wife: This is about a female lawyer who started her own firm and pursued a professional career. Much of the story revolves around the many interactions with her family.'

'Pinterest. A social media website. I love the creative approach. It is almost like an online pin board (a board where one can save for quotes, and notes on fashion and exercises).'

\section{Favourite book or movie}

(Sighs) 'The language of flowers. A beautiful, well-written book. I love the creative language! It is about an orphan girl who learns that different flowers have different meanings. So, when she gives flowers to others, they have different meanings. The story is about her life journey. It reveals how she goes through difficult circumstances and, as a result of that, grows as a person. When she turned 18, she had to go out and find a work and found herself homeless for a while. She first worked for another florist but always wanted to pursue this passion on her own. She then had a baby' (looks up, waves her hand) 'and decided to leave this person ... eventually she could follow her dream and start her own company. Many people flocked to her. The story actually is about love and family; about getting a second chance; about forgiving ... and especially about being able to find a creative and meaningful way to deal with the challenge when one loses one's sense of security and create one's own life.'

\section{Favourite sayings or mottoes}

'A Bible verse: She is clothed in strength and dignity and she laughs without fear of the future' (speaks softly).

'CS Lewis: There are far better things ahead than any you have left behind.'

'CS Lewis: Imagine yourself as a living house (this is a religious quote). You are a house; God knocks down walls, etc. and of course sooner or later it will start to hurt and you do not understand why God is acting in this manner. The quote is all about trusting in God ...' (speaks a little louder) 'trust even though life is hurting; even though it seems difficult.' 


\section{Sylvia's earliest recollections}

\section{Elated youngster enjoys closeness of happy family}

'At the age of three, at my birthday party, the whole family joined in the fun. I remember the snow white birthday cake. I remember so well my young cousin (he was smaller than me). He drove around all the time while I curiously watched him participate in the fun and enjoyment. I enjoyed encouraging him and seeing his enjoyment. We were so happy.'

Emotions associated with the story: joy, happiness, curiosity, love, and excitement

\section{Affectionate interaction with parent brings joy to creative child}

'When I was four years old, at our home in the city ... mmmm' (looks down, smiles) '... Daddy washed his car and involved me. Yes, he made a big effort to involve me in washing the car. He encouraged me to join in. We had lots of fun with the water and the sponges on that sunny day. I remember the driveway vividly; the green colour of the car.' (Illustrates with her finger) 'My parents and I always used to drive around and that was such fun.'

\section{Associated emotions: loving and being loved; joy; excitement}

\section{Confused, heartbroken youngster turns separation into inspiring memory}

(Sighs deeply) 'I was five years at the time. I did not really understand what was happening or what had happened. I remember sitting at the front door, waiting for my father to come home (as I always did). On this day, he did not come home. After I had sat there for quite some time, Mommy came to me, crying, and said that he would not come home again ever.'

(Remains silent for a while) 'That is the story.' (Sighs) 'I remember them fighting often. My parents were not good at communication between themselves but good at communicating what was happening to me.' (Shakes her head from left to right as if to say 'no') 'I am trying to go through a checklist in my mind to revisit this painful story more accurately.'

\section{Associated emotions: sadness, confusion}

Sylvia chose the following encompassing/inclusive heading for the three stories: Excited and joyful child celebrates and cherishes family (life) despite separation

\section{CONSTRUCTING A LIFE PORTRAIT FOR SYLVIA}

Sylvia and I subsequently constructed the following life portrait for her.

In Step 1, Sylvia's response to the first question (which generally indicates a client's goals regarding career counselling) was carefully considered. This response (lack of passion, 
indecision - confusion about her future plans - and feelings of insecurity) reveals both the challenge she is facing currently and her plan for dealing with indecision. Standing at a crossroads, she is seeking guidance to help her regain a sense of joy and fulfilment. She has to choose between working on her own or with somebody else for a while, the kind of work she wants to do, and her doctoral studies.

In Step 2, we used Sylvia’s earliest recollections to identify her key life themes (problems or preoccupations).

Sylvia's first memory is of a happy family gathering where all the significant people in her life were present and having fun. She almost desperately wants to restore that time of togetherness, happiness, and joy (a central life problem).

Sylvia's first verb is 'joined (in the fun)'. She speaks about her sadness and confusion when her world was torn apart so suddenly and unexpectedly and her desire to restore the broken relationship between her parents. Her advice to herself is to maintain, appreciate, and celebrate the relationship with both parents despite knowing that they would never be together again. While she recounted her stories, I repeated certain key words (such as 'joy', 'togetherness', 'fun', 'confusion', and 'sadness') and asked her to clarify the meaning of the key words and phrases. Narratability was promoted by making sure that she was listening to herself carefully and actually hearing what she was saying.

Sylvia drew on her own story for advice thus facilitating autobiographicity. While she could not reunite her parents, she could control her reaction to the divorce and cherish and love both parents.

Sylvia disconsolately reflected on her third story:

'This is not a happy memory. It deals with my parents separating during difficult times.' (Laughs painfully; tears well up in her eyes) 'The main thing that was communicated to me at the time was that it was not my fault ... thinking about that, I find it very interesting. (Sighs deeply) 'I think that is the story that influenced me most.'

(Looks up) Sylvia assures herself that she need not feel guilty about her parents' divorce (a common reaction when parents divorce). Moreover, she realises that the divorce, painful as it was, did not mean that her parents no longer loved her - just the opposite. She intends to embrace them as much as she has always done and believes that she can use her studies to actively master what she had passively suffered. She realises that by helping others ('children in particular') to heal while practising as a psychologist, she will actually also be healing herself. She realises that her current experience of standing at a crossroads may have resulted from her thinking that she may not have the opportunity in her future career to work with children. She has now had the opportunity to listen to herself ('be heard') and can now choose to let go of any silent or subconscious (unarticulated) guilt feelings and draw on her own story to inspire others who may be in a situation similar to hers.

In Step 3, we analysed what the people Sylvia admired the most represented to her so that we 
could establish who she is or wants to be, her fundamental life goals, and the solutions she proposes to her key life problems. Sylvia's role models display many common traits and confirm her central life goal as well as her proposed solutions to the major challenges she is facing. Being a kind, creative, compassionate, artistic, and compassionate person, she wants people (children in particular) to be given the opportunity to be heard (listened to) (another central life goal). She wants to make sure that children have fun while growing up and developing, and she wants to take a personal interest in each child (another central life goal).

In Step 4, we analysed Sylvia's favourite magazine, TV programme, and website to establish the settings or environments that best fit her preferred lifestyle. She wants to work in an environment where she can actualise her sense of creativity. She wants to help people draw on their own inner strength in times of need. She wants to work in a context that allows her to have fun with others and also help people solve their own problems and 'dilemmas'. She wants to work on her own so as to limit the possibility of others imposing restrictions on her creativity. Finally, she wants to take good care of herself and develop her potential to the full.

In Step 5, we analysed Sylvia's favourite book to see if it contained a character facing a problem similar to hers and how the character solved the particular problem. The language of flowers is a story about a young woman who suffered great emotional pain (as a result of what her parents had done) but triumphed over adversity. Sylvia wishes to deal with her own problems as effectively as the young woman in the story had done. More than anything, she wants to be independent and help others who have suffered emotionally. Working for or in another psychologist's practice would be limiting and deny her the freedom to be creative and independent. As a religious person, she wants to enjoy life, love and be loved, take care of her family, forgive people and help others forgive, and give those that have hurt others a second chance. Sylvia is thus looking for a creative and meaningful way to help others actively master what they have passively suffered, make themselves heard, and deal with confusion and insecurity.

In Step 6, Sylvia used her three favourite mottoes or quotations to advise herself on how to 'heal herself'. She wants to be strong, act in a dignified manner, and look forward to rather than fear the future. She strongly believes that great things lie in store for her; that God is building a 'palace' for her - a joyful and happy life. Even though she knows that life is often painful and that there are no guarantees that she will not experience hurt in the future, she knows that her trust in God will always help her deal with and rise above life's challenges.

In Step 7, fields of study, we discussed occupations and work environments that might be appropriate ('fitting') for Sylvia. Recommended fields for investigation were a Master's degree 
in Counselling or Educational Psychology, followed by short courses on, for example, cooking, decorating, scrapbooking, writing, drama, and art therapy. In the longer term, she could enrol for a doctoral degree on, for example, how children can be helped deal with divorce and separation. We determined that she should investigate the possibility of working on her own as soon as possible after qualifying as a psychologist.

\section{Life Portrait: Sylvia}

(For easy reference, S1 refers to the first step in the creation of the life portrait, CCIQ1 to Sylvia's response to the first question in the CCI, and so on.)

(S1) 'Hopefully I will learn more about myself ... about what I did not realise or thought about before. I am unsure as to whether I should go into private practice or link up with somebody else first. I am somewhat uncertain, too, about whether I should pursue my doctorate in psychology at a later stage.’

(S2, CCIQ5) 'When I was very young, my parents divorced ... for me, as a very young girl, that was a sad and devastating experience (a preoccupation; a central life theme). I cherished the togetherness and belongingness of Mommy, Daddy and me immensely. I realise how important it is for parents and their children to spend fun time together and have joy.'

'That led to my developing a strong passion to encourage and inspire young children; especially to help children who have suffered trauma (such as seeing their parents get divorced). I believe that it is possible to remain excited and joyful; to celebrate and cherish family life ... to ensure that families grow in spite of pain.'

(S3, CCIQ1) 'I am a beautiful, graceful, caring, disciplined, dedicated, compassionate, friendly, arty, sporty and deeply religious young woman. It is important to me to take time to get to know people well, take a personal interest in them, make them feel special (children in particular - they deserve a personal touch). I am independent ... arriving at decisions of my own accord is important to me. I want be the best person and psychologist I can be; a person that will be capable of helping people (children in particular) to construct themselves adequately, despite sometimes having to overcome personal trauma.'

(S4, CCIQ2) 'I enjoy creative activities, exercising, reading, singing, and dressing in a stylish manner. Working with people in an environment where I can help people (children in particular) advise themselves by engaging them in problem solving; helping people deal with dilemmas has always been a great passion of mine. I just have to work with people and help them resolve personal issues.'

'I guess part of me is also keenly interested in making sure that people are given the opportunity to be heard.'

(S5, CCIQ3) 'I had to live through painful experiences on life's journey. A genuinely resilient woman, I have grown immensely as a result of this ... I have acquired the skill to be kind to different people in different ways (depending on their idiosyncratic needs). I respect women who are courageous, who are willing to sacrifice independence in their work environment for a while if it is in their best, long-term interests; especially if that will help them to become independent, start their own business and be hugely successful.'

(S6, CCIQ4) 'I am a strong and dignified woman. I enjoy life in a responsible manner and I do not fear the future. As the song goes: I know not what the future holds but I know Who holds the future. The best in my life is yet to come. Yes, I have suffered and experienced sadness but I know that God always knows what is best for me. God has challenged me but He also was always there to pick me up and hold me to His bosom when I was down. I trust my dear Saviour unconditionally and I always will.' 
(S7) 'I then asked her to compose her mission statement (MS), and this is what she and I decided on: I will complete my Master's degree, do my internship, link with an established person or entity to help me make a name for myself, fine tune my existing skills, learn how to run a private practice and, when the time is ripe, start my own business and become hugely successful ... especially in the sense that I will be useful to many people who are in need of counselling.'

'I will put the decision as to whether I want to pursue my doctoral studies (including the topic that I want to work on) on hold for the time being. What has become clear to me is that there are many topics that I could possibly consider but that working with children who have suffered trauma and helping them to turn their pain into hope and a social contribution would probably form the basis of my choice.'

'In doing what I will be doing, I will be honouring the legacy of my beloved mother and father.'

Sylvia and I used this MS to identify the resources she needed to devise a feasible action strategy to realise her stated aims. The plan of action was, first, to work as hard as she could to complete her studies. She could talk to people, volunteer to work in a private practice, investigate the possibility of starting her own practice as soon as she had completed her degree or perhaps work with someone she felt comfortable with for a while. I also advised her to attend short courses on how to start a private practice.

(S8) Lastly, I asked Sylvia to write a response to her original request for career counselling. She responded by saying: 'The interview was an amazing for me. It enabled me to see how the thread of my life was interwoven in my current choices and this was incredible to see. It made me think of things in depth; things that I would not usually have allowed myself to think of. It enabled me to reflect on my own life and to start to draw associations with my career choices and life history and reflect on who I am as a person. The penny dropped when I realized why I want to work with children - a culmination of my past experiences. I am looking forward to seeing how my future enfolds.'

'The life portrait has shown me just how valuable this process is; it is amazing how accurate this document is. I am looking forward to my future.’

I then suggested she return home, consider possible options for dealing with the challenges confronting her, and report back to me if and when she wanted to.

\section{LIMITATIONS}

As a researcher in the social sciences, I was subjectively immersed in this study and interpreted the data from this perspective. I am aware that my judgment was not only shaped by the data but also by my personal feelings, interests, opinions and my own career-life story. Some researchers, who prefer a more quantitative approach to career counselling, believe that qualitative approaches should be shown to have more proven scientific credibility. 


\section{ADVICE TO OTHERS WHO MAY WISH TO CONDUCT THIS TYPE OF INTERVENTION AND ANALYSIS}

First, acceptance of the value of narrative approaches to career counselling in addition to 'positivist' approaches is essential. Second, career indecision is a perfectly justifiable phenomenon and should be treated as such, even more so when one considers the rapid changes taking place in society today. Third, it is important to classify the reasons for career indecision and to tailor interventions accordingly. Indecision often occurs 'naturally' (e.g. when clients are faced with 'normal' transition, such as choosing a field of study at the end of their school career). However, sometimes it is prompted by deeper-seated motivation (e.g. when a client who has been retrenched as a result of his inability to deal with people or his depression). It is sometimes necessary to deal with the deeper-seated challenge first What may be seen as taking a step back is, in fact, an essential part of moving forward to help the client deal with the challenge and turn (perceived) indecision into resolution (Duarte 2009; Maree 2013; Savickas 2011).

\section{RECOMMENDATIONS}

Firstly, career counsellors who are not familiar with the narrative approach should attend training courses on this approach as well as on the integrated approach to career counselling. Secondly, they should receive training in the theoretical and practical underpinnings of the CCI and in the broader notion of life design counselling. Thirdly, research is needed to establish the long-term impact of the CCI (and other narrative techniques and interventions). Fourthly, research is also needed on the viability of the CCI and other qualitative techniques and interventions in group-based and non-traditional contexts. Lastly, given the large number of students who present with career indecision, a way needs to be found to enable as many students as possible to have access to the career counselling approach advocated here.

\section{FOLLOW-UP}

Follow-up was requested on an ongoing basis (as Sylvia saw fit and depending on her schedule) to monitor Sylvia's progress and to enable me to assess the usefulness of the intervention from her perspective. It was undertaken after one, two, and six months, respectively. The time-frame was determined by Sylvia. After six months, she commented:

'My experience of the CCI was very positive. It was phenomenal to see the way in which the CCI knitted the aspects of my life together into an interconnected tapestry. It was a truly humbling experience and I was incredibly grateful for the opportunity. I feel that the CCI and consequential Life Portrait accurately captured myself as a person. It depicted my life themes impeccably. I was 
speechless when I read my Life Portrait as it knitted so many aspects of my life into a tapestry that depicted the main fundamentals of who I am as a person. The emphasis on God as well as the fortitude in which I used to face life's adversities, was very accurate. It was amazing to see how the questions from the CCI were used to explore the questions that I had posed. It was also incredible to see the way in which the questions in the CCI linked together to create a rich narrative or tapestry regarding my story or my life's portrait.'

'I feel that the CCI is a useful strategy that can be used to unlock people's potential. It helped me gain insight into my plans for the future by connecting aspects of my own life in a personalized and individual-focused approach.'

\section{DISCUSSION}

This case study demonstrated the value of career construction counselling for a client battling with career indecision. The study also showed that this approach can help students in general deal with challenges experienced while they are studying. Their ability to narrate their stories and draw upon them in times of indecision will help them deal with transitions as and when they occur. The study confirmed Krieshok's (1998) view that decision making is not simply a linear, rational process but, rather, a complex process often involving subconscious motivations. The findings also reveal that career indecision may be brought about by (conscious and subconscious) emotional problems (Di Fabio and Kenny 2011; Fouad et al. 2006). Hartung (2016), Heppner et al. (2004), and Masdonati, Massoudi and Rossier’s (2009) findings, too, were substantiated as they indicated that individual career counselling reduced problems related to career decision making (also see Heppner, Multon, Gysbers, Ellis and Zook 1998).

The present study results are also consistent with those of Braunstein-Bercovitz, Benjamin, Asor and Lev (2012) and Kim, Kang, Cho and Lee (2011), who established a significantly positive correlation between the quality of the relationship between clients and their parents and career indecision. They also reflect the view of Kim, Kang and Kim (2013) that conflict between parents and their children can impact negatively on the children's career decision-making confidence.

The subconsciously induced central life themes (revealed by the three earliest recollections) of the participant in the present study suggest that the CCI could be used in addition to the administration of a career indecision scale to identify reasons for career indecision not identified by current career indecision questionnaires. Moreover, the 'advice' offered by the participant to herself (through the responses to the first four questions) seemed extremely useful in finding ways to resolve her career indecision. The use of the CCI (in addition to career indecision scales) not only as an assessment instrument but, more importantly, as a therapeutic technique to resolve career indecision is therefore strongly recommended. Understanding their central life themes will help clients with career indecision 
appreciate the importance of not choosing a field of study solely on the basis of test results and expecting to be successful in the associated career. They should first of all clarify the initial pain they wish to master and build upon this insight when they choose careers and construct themselves. In doing so, they will be able to turn their pain into hope, heal themselves and others, and make substantial social contributions.

\section{CONCLUSION}

The strategy advocated in this article presents an exciting opportunity to blend career counselling theory, research, and practice. Drawing on career construction counselling by using the CCI and crafting life portraits turns career counselling assessment into a therapeutic strategy and should ideally be the right of every student. Career counsellors working from a narrative framework are well situated and equipped to implement this strategy in contexts of indecision. The theoretical and practical approach to career counselling discussed in the article can provide professionals with an exciting strategy for facilitating storied career counselling by storying and restorying themselves (Clandinin and Connelly 1999) in collaboration with empathetic career counsellors. Moreover, this approach confirms Krieshok, Black and Mckay’s (2009) view that subconscious processes may well play a major role in career decision making.

\section{ACKNOWLEDGEMENT}

I would like to thank the client for participating in the study and Tim Steward for editing the text.

\section{NOTES}

1. The verbatim responses of the participant have been only lightly edited to preserve their authenticity.

2. A guiding line rather than a role model.

\section{REFERENCES}

Adler, A. 1932. What life should mean to you. London, England: Allen and Unwin Ltd.

Alheit, P. and B. Daussien. 1999. Biographicity as a basic resource of lifelong learning. Paper presented at the second European conference on lifelong learning. February, Bremen, Germany.

Blustein, D. L., M. V. Ellis and L. Devenis. 1989. The development and validation of a two-dimensional model of the commitment to career choice process. Journal of Vocational Behavior 35(3): 342378.

Braunstein-Bercovitz, H., B. A. Benjamin, S. Asor and M. Lev. 201. Insecure attachment and career indecision: Mediating effects of anxiety and pessimism. Journal of Vocational Behavior 81(2): 236-244.

Clandinin, D. J. and F. M. Connelly. 1999. Storying and restorying ourselves: Narrative and reflection. In The reflective spin: Case studies of teachers in higher education transforming action, ed. A-Y. 
Chen and J. van Maanen, 15-24. River Edge, N.J.: World Scientific Publishing.

Cochran, L. (1991). Life-shaping decisions. New York, NY: Lang.

Creed, P., N. Buys, C. Tilbury and M. Crawford. 2013. The relationship between goal orientation and career striving in young adolescents. Journal of Applied Social Psychology 43(7): 1480-1490.

Di Fabio, A. and M. Kenny. 2011. Promoting emotional intelligence and career decision making among Italian high school students. Journal of Career Assessment 19(1): 21-34.

Di Fabio, A. and J. G. Maree. 2013. Career construction and life design: Heralding a new beginning to career counselling in the 21st century. In Psychology of career counselling: New challenges for a new era, ed. A. Di Fabio and J. G. Maree, 1-15, Hauppauge, NY: Nova Science.

Duarte, M. E. 2009. The psychology of life construction. Journal of Vocational Behavior 75(3): 259266.

Elo, S., M. Kääriäinen, O. Kanste, T. Pölki, K. Utriainen and H. Kyngäs. 2014. Qualitative content analysis: A focus on trustworthiness. SAGE Open 4(1):1-10.

Fouad, N. A., A. Guillen, E. Harris-Hodge, C. Henry, A. Novakovic, S. Terry and N. Kantamneni. 2006. Need, awareness, and use of career services for college students. Journal of Career Assessment 14(4): 407-420.

Garcia, P. R., S. L. Restubog, L. S. Toledano, L. R. Tolentino and A. E. Rafferty. 2012. Differential moderating effects of student-and parent-rated support in the relationship between learning goal orientation and career decision-making self-efficacy. Journal of Career Assessment 20(1): 22-33.

Gati, I., M. Krausz and S. H. Osipow. 1996. A taxonomy of difficulties in career decision making. Journal of Counseling Psychology 43(4): 510-526.

Gati, I., S. H. Osipow, M. Krausz and N. Saka. 2000. Validity of the Career Decision-Making Difficulties Questionnaire: Counselee versus career counsellor perceptions. Journal of Vocational Behavior 56(1): 99-113.

Gianakos, I. 2001. Predictors of career decision-making self-efficacy. Journal of Career Assessment 9(2): 101-114.

Guay, F., C. Sene'cal, L. Gauthier and C. Fernet. 2003. Predicting career indecision: A selfdetermination theory perspective. Journal of Counseling Psychology 50(2): 165-177.

Guichard, J. 2009. Self -constructing. Journal of Vocational Behavior 78(3): 251-258.

Hartung, P. J. 2011. Career construction: Principles and practice. In Shaping the story: A guide to facilitating narrative career counselling, ed. K. Maree, 103-120. Rotterdam, The Netherlands: Sense.

Hartung, P. J. 2016. Career decidedness. The Career Development Quarterly 64(1): 2-3.

Heppner, M. J., D-w. Lee, P. Heppner, L. C. McKinnon, K. D. Multon and N. C. Gysbers. 2004. The role of problem-solving appraisal in the process and outcome of career counselling. Journal of Vocational Behavior 65(2): 217-238

Heppner, M. J., K. D. Multon, N. C. Gysbers, C. A. Ellis and C. E. Zook. 1998. The relationship of trainee self-efficacy to the process and outcome of career counselling. Journal of Counseling Psychology 15(4): 393-402.

Kim, C., M. Kang and Y. Kim. 2013. Effect of conflictual independence from and attachment to mother on career indecision: The mediating effect of indecisiveness and relative effect sizes of the two independent variables. Journal of Asia Pacific Counselling 3(2): 151-164.

Kim, Y., M. Kang, A. Cho and Y. Lee. 2011. The moderating effect of psychological separation and indecisiveness on the relations among attachment, career decision-making self-efficacy and career indecision. The Korean Journal of Counseling and Psychotherapy 23(4): 995-1016.

Krieshok, T. S. 1998. An anti-introspectovist view of career decision making. Journal of Career Development 46(3): 210-229.

Krieshok, T. S., M. D. Black and R. A. Mckay. 2009. Career decision making: The limits of rationality 
and the abundance of non-conscious processes. Journal of Vocational Behavior 75(3): 275-290

Lease, S. H. 2004. Effects of locus of control, work knowledge, and mentoring on career decisionmaking difficulties: Testing the role of race and academic institution. Journal of Career Assessment 12(2): 239-254.

Maree, J. G. 2013. Counselling for career construction: Connecting life themes to construct life portraits. Turning pain into hope. Rotterdam, The Netherlands: Sense.

Maree, J. G. 2015. Life themes and narratives. In APA handbook of career intervention. Vol. 2: Applications, ed. P. J. Hartung, M. L. Savickas and W. B. Walsh, 225-239. New York, N. Y.: American Psychology Association.

Martin, C. R. 1995. Looking at type and careers. Gainesville, FL: Center for Applications of Psychological Type.

Masdonati, J., K. Massoudi and J. Rossier. 2009. Effectiveness of career counselling and the impact of the working alliance. Journal of Career Development 36(2): 183-203.

Parsons, F. 2005. Choosing a vocation. Broken Arrow, OK: National Career Development Association.

Richardson, M. S. 1993. Work in people’s lives: A location for counselling psychologists. Journal of Counseling Psychology 40(4): 425-433.

Savickas, M. L. 1995. Constructivist counselling for career indecision. Career Development Quarterly 43(4): 363-375.

Savickas, M. L. 1998. Career style assessment and counselling. In Adlerian counselling: A practitioner's approach, ed. T. Sweeney, 329-360. 4th Edition. Philadelphia, PA: Accelerated Development.

Savickas, M. L. 2005. The theory and practice of career construction. In Career development and counselling: Putting theory and research to work, ed. S. D. Brown and R.W. Lent, 42-70. Hoboken, NJ: John Wiley and Sons.

Savickas, M. L. 2009a. The role of values in careers: Meaning and mattering in life design. Millennium Centre, University of St Louis, St Louis, MO: USA.

Savickas, M. L. 2009b. Career-style counselling. In Adlerian counselling and psychotherapy: A practitioner's approach, ed. T. J. Sweeney, 183-207. $5^{\text {th }}$ Edition. New York, NY: Routledge.

Savickas, M. L. 2010. Vocational counselling. In Corsini's encyclopedia of psychology, ed. I. B. Weiner and W. E. Craighead, 1841-1844. $4^{\text {th }}$ Edition. Hoboken, NJ: John Wiley and Sons.

Savickas, M. L. 2011. Career counselling. Washington, DC: APA.

Savickas, M. L. 2013. The theory and practice of career construction. In Career development and counselling: Putting theory and research to work, ed. S. D. Brown and R. W. Lent, 147-186. $2^{\text {nd }}$ Edition. Hoboken, NJ: Wiley.

Savickas, M. L. 2015a. Career counselling paradigms: Guiding, developing, and designing. In The APA handbook of career intervention Vol. 1, eds. P. J. Hartung, M. L. Savickas, and W. B. Walsh, 129143. Washington, DC: APA Books.

Savickas, M. L. 2015b. Designing projects for career construction. In Counseling and action: Toward life-enhancing work, relationships, and identity, ed. R. A. Young, J. F. Domene and L. Valach, 13-31. New York, NY: Springer Science+Business Media.

Savickas, M. L. 2015c. Life-design counseling manual. Rootstown, OH: Author.

Savickas, M. L. and D. Jarjoura. 1991. The Career Decision Scale as type indicator. Journal of Counseling Psychology 38(1): 63-81

Savickas, M. L., L. Nota, J. Rossier, J.-P. Dauwalder, M. E. Duarte, J. Guichard and A. E. M. Van Vianen. 2009. Life designing: A paradigm for career construction in the 21th century. Journal of Vocational Behavior 75(3): 239-250.

Stringer, K., J. Kerpelman and V. Skorikov. 2011. Career preparation: A longitudinal, process-oriented examination. Journal of Vocational Behavior 79(1): 158-169.

Sweeney, T. J. and J. E. Myers. 1986. Early recollections: An Adlerian technique with older people. The 
Clinical Gerontologist 4(4): 3-12.

Taylor, K. M. and N. E. Betz. 1983. Applications of self-efficacy theory to the understanding and treatment of career indecision. Journal of Vocational Behavior 22(1): 63-81.

Winnicott, D. W. 1969. The use of an object and relating through identifications in playing and reality. London, England: Routledge. 